\title{
Magnesian tourmalines from plagioclase-muscovite-scapolite metaevaporite layers in dolomite marble near Prosetín (Olešnice Unit, Moravicum, Czech Republic)
}

\author{
Peter BAČík ${ }^{1, *}$, Pavel UHER ${ }^{1}$, Jan CEMPÍREK ${ }^{2,3}$, Tomáš VACULOVIČ4 \\ ${ }^{1}$ Comenius University in Bratislava, Faculty of Natural Sciences, Department of Mineralogy and Petrology, Mlynská dolina, 84215 \\ Bratislava, Slovak Republic; bacikp@fns.uniba.sk \\ ${ }^{2}$ Department of Mineralogy and Petrography, Moravian Museum, Zelný trh 6, 65937 Brno, Czech Republic \\ ${ }^{3}$ Department of Earth and Ocean Sciences, University of British Columbia, 6339 Stores Road, Vancouver, BC, V6T 164 Canada \\ ${ }^{4}$ Central European Institute of Technology, Masaryk University, Kamenice 5, 62500 Brno, Czech Republic \\ ${ }^{*}$ Corresponding author
}

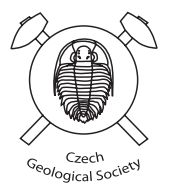

Radial aggregates of blue-grey tourmaline were found in plagioclase-muscovite-scapolite metaevaporite layers in dolomite marble near Prosetín (Olešnice Unit, Moravicum, Czech Republic). It occurs in association with plagioclase $\left(\mathrm{An}_{15-37}\right)$, muscovite, scapolite, phlogopite, vermiculite, pumpellyite-(Al), and clinozoisite. Electron-microprobe analyses of tourmaline show dravitic composition with very high content of $\mathrm{Mg}$ (1.92 to 2.77 apfu), $\mathrm{Al}$ (up to 6.71 apfu), low content of $\mathrm{Fe}$ (up to $0.39 \mathrm{apfu}$ ) and variable amounts of vacancies (0.09 to 0.47 ) and $\mathrm{Ca}(0.03$ to 0.29 apfu) in the $X$-site. Some analyses correspond to "oxy-dravite" and some others almost attain magnesio-foitite compositions. The proportion of $X$-site vacancy decreases from the crystal cores to their rims while Ca content increases. Generally, charge excess due to the high Al-contents is balanced either by an increasing $X$-site vacancy or by deprotonization of ${ }^{W} \mathrm{OH}$; the ${ }^{W} \mathrm{O}^{2-}$ content calculated from charge-balanced formula attains $0.71 a p f u$. Lattice parameters $[a=15.9116(6) \AA ; c=7.1987(4) \AA]$ and deduced average bond lengths $(<Y-\mathrm{O}>=1.995 \AA ;\langle Z-\mathrm{O}>=1.929 \AA)$ indicate a relatively high $\mathrm{Al}-\mathrm{Mg}$ disorder. Three main substitution mechanisms are inferred to operate in the studied magnesian tourmalines: (1) $\mathrm{CaMg}(\mathrm{NaAl})_{-1}$, mainly in Ca-enriched dravite, (2) ${ }^{X_{\square}} \mathrm{Al}(\mathrm{NaMg})_{-1}$ in nearly magnesio-foititic compositions, and (3) $\mathrm{AlO}(\mathrm{MgOH})_{-1}^{-1}$ in "oxydravitic" members. The tourmaline is relatively poor in trace elements; only Ti, Sr, and Ga exceed 100 ppm according to LA-ICP-MS study. There is a pronounced positive correlation between $\mathrm{Sr}$ and $\mathrm{Ca}\left(r^{2}=0.77\right)$, which suggests that $\mathrm{Sr}$ accumulated in Ca-enriched zones of dravite. The pale blue-grey color of the studied tourmalines is most likely a result of $\mathrm{Fe}^{2+}$ crystal field transitions along with the absence of significant amounts of other chromophores. Trace-element contents, mineral assemblage and compositional zoning of tourmalines as well as host-rock mineral association suggest prograde metamorphic growth and support metaevaporitic origin of the plagioclase-muscovite-scapolite rocks.

Keywords: tourmaline, dravite, oxy-dravite, crystal chemistry, metaevaporites, Bohemian Massif

Received: 17 May 2012; accepted: 14 September 2012; handling editor: M. Novák

\section{Introduction}

Extremely magnesian tourmaline including dravite, "oxy-dravite" and magnesio-foitite is confined to specific genetic environment. It requires high atomic $\mathrm{X}_{\mathrm{Mg}}[\mathrm{Mg} /(\mathrm{Mg}+\mathrm{Fe})]$ ratio in the host rock, and thus is characteristic of metaultramafic rocks, metapyroxenites, or metacarbonates (Henry and Guidotti 1985). Another typical host for highly magnesian tourmalines are metaevaporites, where oxy-dravite and dravite frequently occur (Henry et al. 1999, 2008; Žáček et al. 2000; Bačík et al. 2008). This compositional feature of tourmaline is attributed to the influence of oxidizing, highly saline, boron-bearing fluids associated with such lithologies (Henry et al. 2008). Formation of tourmaline is a result of subsequent metamorphic events, whereby the high
$\mathrm{X}_{\mathrm{Mg}}$ ratio is determined by the bulk composition of the host Mg-rich marine evaporite.

Plagioclase-muscovite-scapolite rock layers in dolomite marble near Prosetín (Olešnice Unit, Moravicum, Czech Republic) host tourmaline which belongs to dravite-oxy-dravite and dravite-magnesio-foitite solid solutions. Although it has been studied previously by powder X-ray diffraction (XRD), wet chemical analysis (Povondra and Novák 1986) and also electron microprobe analysis (EMPA) (Opletal 2009), we bring new detailed mineralogical and crystallochemical data resulting from application of EMPA, powder XRD, and Laser Ablation Inductively Coupled Plasma Mass Spectrometry (LAICP-MS). These provide new insights on the tourmaline composition, structural properties, origin, and on the chromophores responsible for its blue-grey color. 


\section{Geological setting}

The studied locality belongs to Olešnice Unit, Moravicum, which is a part of the Moravo-Silesian Zone in the eastern Bohemian Massif. The Moravo-Silesian Zone represents a Hercynian nappe complex which is structurally underlying the Moldanubian metamorphic complex (Neubauer and Handler 2000; Finger et al. 2007; Schulmann et al. 2008). The Moravo-Silesian Zone represents a NE-SW trending belt of Neoproterozoic to Lower Paleozoic sheared and metamorphosed rocks derived from the Brunia microcontinent (Kalvoda et al. 2008). This $\sim 300 \mathrm{~km}$ long, 30 to $50 \mathrm{~km}$ wide belt consists of three NE-SW-elongated tectonic windows emerging through structurally overlying high-grade rocks of the Moldanubian-Lugian domain: southern Thaya Window; central Svratka Window and northern Silesian domain (Schulmann et al. 2008). The Moravo-Silesian Zone developed during Carboniferous dextral-oblique thrusting of the Moldanubian-Lugian domain (Schulmann et al. 1991).

The lithotectonic structure of the Svratka Window (including the Olešnice Unit) is, from bottom to top and from the East to the West, as follows: (1) The Parautochthonous domain (chlorite zone), (2) Lower Moravian Nappe (biotite zone), and (3) Upper Moravian Nappe (garnet zone). Consequently, the Svratka Window is characterized by inverted Barrovian metamorphic zonation (Ulrich et al. 2002). The Olešnice Unit (Olešnice-Vranov Unit) represents a variegated lithologic sequence of predominantly Devonian (?) metamorphic rocks, mainly mica schists and paragneisses, graphitic metapelites, quartzites, calcite and dolomite marbles, rarely amphibolites and metagabbros (Sekanina 1965a; Opletal et al. 2007). The tremolitebearing marbles of the Olešnice Unit build the upper parts of the Upper Moravian Nappe, where they form large bodies (up to $50 \mathrm{~m}$ thick) set in a complex of dominant muscovite-biotite metapelites (mica schists and gneisses) metamorphosed in amphibolite facies (garnet zone). The $\mathrm{P}-\mathrm{T}-\mathrm{X}$ conditions of metamorphism of these marbles were estimated from stability of the assemblages tremolite + calcite + quartz and tremolite + dolomite, corresponding to $\mathrm{T}_{\max }=580-620^{\circ} \mathrm{C}$ at $\mathrm{X}\left(\mathrm{CO}_{2}\right)=0.2-0.7$ and $\mathrm{T}_{\min }=480-530^{\circ} \mathrm{C}$ at $\mathrm{X}\left(\mathrm{CO}_{2}\right)=$ $0.2-0.6$ at $\mathrm{P}_{\text {total }}=500 \mathrm{MPa}$ (Houzar et al. 2000; Houzar and Leichmann 2003).

At the disused Prosetín quarry, the studied locality $\left(49.534933^{\circ} \mathrm{N}, 16.398883^{\circ} \mathrm{E}, 613 \mathrm{~m}\right.$ above sea level), two parallel layers of concordant muscovite-plagioclasescapolite rock are enclosed in dolomite marble; the layers are usually c. $30 \mathrm{~cm}$, locally up to $50 \mathrm{~cm}$ thick. Elsewhere, their thickness reaches only $10 \mathrm{~cm}$ or they wedge out completely (Opletal et al. 2007; Opletal 2009).
There are two hypotheses regarding the origin of plagioclase-muscovite rock layers in dolomite marble near Prosetín. Sekanina (1965b) considered the plagioclase-muscovite rock layers to be intrusions of $\mathrm{SiO}_{2}$-poor aplites (oligoclasites) and explained the scapolite- and tourmaline-bearing mineral association as a result of interaction of hydrothermal fluids with oligoclasite. In contrast, Opletal et al. (2007) showed that plagioclase-muscovite-scapolite rock layers may be of metaevaporitic origin. The latter hypothesis is supported e.g. by the absence of $\mathrm{Mg}$ skarns with diopside and/or forsterite zones, which are otherwise a typical product of the interaction between granitic-pegmatitic magma and dolomites (e.g., Shabynin 1973), absence of lateral veins characteristic of pegmatites and inferred high activity of $\mathrm{Cl}$ required for crystallization of the $\mathrm{Cl}$ enriched marialite $\left(\mathrm{Mar}_{51-59}\right)$ present in the assemblage (Opletal et al. 2007). Two metamorphic phases in the plagioclase-muscovite-scapolite rocks - (1) prograde, producing association of scapolite, phlogopite, part of clinozoisite and plagioclase with $\mathrm{An}_{15-37}$, and (2) retrograde, with albite, chlorite, muscovite and vermiculite - generally correlate with evolution of the surrounding dolomite marble. Plagioclase associated with tourmaline is altered to muscovite, albite, epidote and calcite; the tourmaline assemblage was formed likely at the end of the prograde or at the beginning of the retrograde phase (Opletal et al 2007; Opletal 2009).

\section{Analytical methods}

The composition of tourmaline was established with CAMECA SX100 electron microprobe in wavelengthdispersion mode, at the State Geological Institute of Dionýz Štúr, Bratislava. The analytical conditions were: accelerating voltage $15 \mathrm{kV}$, beam current $20 \mathrm{nA}$, and beam diameter of 3 to $5 \mu \mathrm{m}$. The tourmaline samples were analyzed with the following standards: wollastonite $\left(\mathrm{SiK}_{\alpha}, \mathrm{CaK}_{\alpha}\right), \mathrm{TiO}_{2}\left(\mathrm{TiK}_{\alpha}\right), \mathrm{Al}_{2} \mathrm{O}_{3}\left(\mathrm{AlK}_{\alpha}\right)$, pure $\mathrm{Cr}\left(\mathrm{CrK}_{\alpha}\right)$, pure $\mathrm{V}\left(\mathrm{VK}_{\alpha}\right)$, fayalite $\left(\mathrm{FeK}_{\alpha}\right)$, rhodonite $\left(\mathrm{MnK}_{\alpha}\right)$, forsterite $\left(\mathrm{MgK}_{\alpha}\right)$, willemite $\left(\mathrm{ZnK}_{\alpha}\right)$, pure $\mathrm{Ni}\left(\mathrm{NiK}_{\alpha}{ }_{\alpha}\right)$, albite $\left(\mathrm{NaK}_{\alpha}\right)$, orthoclase $\left(\mathrm{KK}_{\alpha}\right), \mathrm{BaF}_{2}\left(\mathrm{FK}_{\alpha}\right)$ and $\mathrm{NaCl}\left(\mathrm{ClK}_{\alpha}\right)$. Lower detection limits of the measured elements varied between 0.01 and 0.05 wt. \%; V, Cr, Mn, Zn, Ni, F, and $\mathrm{Cl}$ were also below their respective detection limits. The analytical data were normalized according to the PAP procedure (Pouchou and Pichoir 1985). The crystallochemical formulae of tourmaline were calculated on the basis of $15 Y+Z+T$ cations, ${ }^{W} \mathrm{O}^{2-}$ was obtained from the charge-balanced formula, $\mathrm{OH}$ was calculated as $\mathrm{OH}$ $=4-\mathrm{Cl}-{ }^{W} \mathrm{O}$ apfu, $\mathrm{B}=3$ apfu.

Powder X-ray diffraction analyses were made on diffractometer BRUKER D8 Advance (Laboratory of 
X-ray diffraction SOLIPHA, Faculty of Natural Sciences, Comenius University in Bratislava) under following conditions: Bragg-Brentano geometry (Theta-2 Theta), $\mathrm{Cu}$ anticathode $\left(\lambda_{\alpha}=1.54060 \AA\right)$, accelerating voltage $40 \mathrm{kV}$, beam current $40 \mathrm{~mA}$. Ni $\mathrm{K}_{\beta}$ filters were used for stripping of $\mathrm{K}_{\beta}$ radiation on the primary and diffracted beam, and data were acquired by the BRUKER LynxEye detector. The step size was $0.01^{\circ} 2 \Theta$, the step time $5 \mathrm{~s}$ per step, and the range of measurement 4 to $65^{\circ} 2 \Theta$. Measured data were evaluated with the DIFFRAC ${ }^{\text {plus }}$ EVA software package. Analyzed scans were fitted by, and lattice parameters refined with, the DIFFRAC plus TOPAS software on a basis of dravite structure (sample 32008, Bloodaxe et al. 1999). Average bond lengths in octahedra were calculated from lattice parameters according to empirical formulae: $a=13.045+1.437\langle Y$-O $\rangle$ $\AA ; c=0.886+3.272<Z$-O $>\AA$ (Bosi and Lucchesi 2004). Subsequently, it allowed to calculate ${ }^{Z} \mathrm{Mg}$ in crystallochemical formulae according to empirical formula ${ }^{\mathrm{Z}} \mathrm{Mg}$ $=49.697\langle Z-\mathrm{O}\rangle-94.845$ (Ertl et al. 2010).

The LA-ICP-MS analyses were carried out by a laser ablation system UP 213 (New Wave, USA) attached to a quadrupole ICP-MS Agilent 7500 CE (Agilent, Japan), at the Central European Institute of Technology, Masaryk University, Brno. The Q-switched Nd-YAG laser emits radiation with wavelength of $213 \mathrm{~nm}$. The sample gas flow of $\operatorname{Ar}(0.6 \mathrm{l} / \mathrm{min})$ was admixed to the He carrier gas $(1.0 \mathrm{l} / \mathrm{min})$ behind the laser ablation cell. The LA-ICP-MS parameters were optimized using the glass reference material NIST SRM 612 to yield a maximum signal to noise ratio. Hole drilling mode of laser ablation was utilized with spot diameter $65 \mu \mathrm{m}$, laser beam fluency $18 \mathrm{~J} . \mathrm{cm}^{-2}$ and repetition rate $10 \mathrm{~Hz}$, ablating for $40 \mathrm{~s}$ at each spot. All element contents were normalized using $\mathrm{Si}$ as an internal standard; its content was obtained by EMPA.

\section{Results}

Tourmaline from Prosetín forms radial aggregates of blue-grey prismatic crystals, up to $3 \mathrm{~cm}$ across (Fig. 1). It has very weak chemical zoning; three compositional types of tourmaline were recognized, occurring in variable proportions. Two zones can be distinguished in BSE: light one, generally forming cores of crystals (if they are defined by surfaces of prisms), and dark one, on the rim (Fig. 2). The light zone consists of two phases with different chemical compositions: (1) tourmaline with higher $X$-site vacancy and compositions changing from dravite toward magnesio-foitite, and (2) tourmaline with low $X$-site vacancy and $\mathrm{Ca}$ concentrations which attains the oxy-dravite composition (Tab. 1, Figs 2 to 4). The dark zone at the rim (Fig. 2 - phase no. 3 ) is formed by dravite with increased $\mathrm{Ca}$ (Tab. 1, Figs 2 to 4). The enrichment in $\mathrm{Ca}$ is likely the result of the uvite substitution mechanism, $\mathrm{CaMg}\left(\mathrm{NaAl}_{-1}\right.$ (Fig. 5a).

All zones of the Prosetín tourmaline are strongly magnesian $\left(\mathrm{X}_{\mathrm{Mg}}=0.85-0.92\right.$, and up to 0.97 in $\mathrm{Ca}$ enriched dravite; Tab. 1). The studied tourmaline has an increased content of Al relative to the ideal composition of dravite. In dravite to magnesio-foitite, it varies between 6.42 and $6.48 \mathrm{apfu}$, and between 6.28 and 6.72 apfu in oxy-dravitic zones. The lowest content of $\mathrm{Al}$ is in Ca-enriched compositions, but still reaches up to 6.25 apfu Al (Fig. 4, Tab. 1). The increased Al contents may be charge-balanced by the increase in $X$-site vacancy due to the ${ }^{X} \square \mathrm{Al}(\mathrm{NaMg})_{-1}$ substitution (Fig. 5b). However, this mechanism may be significant only in the dravite-magnesio-foitite phase, as the proportion of $X$-site vacancy in oxy-dravite is too

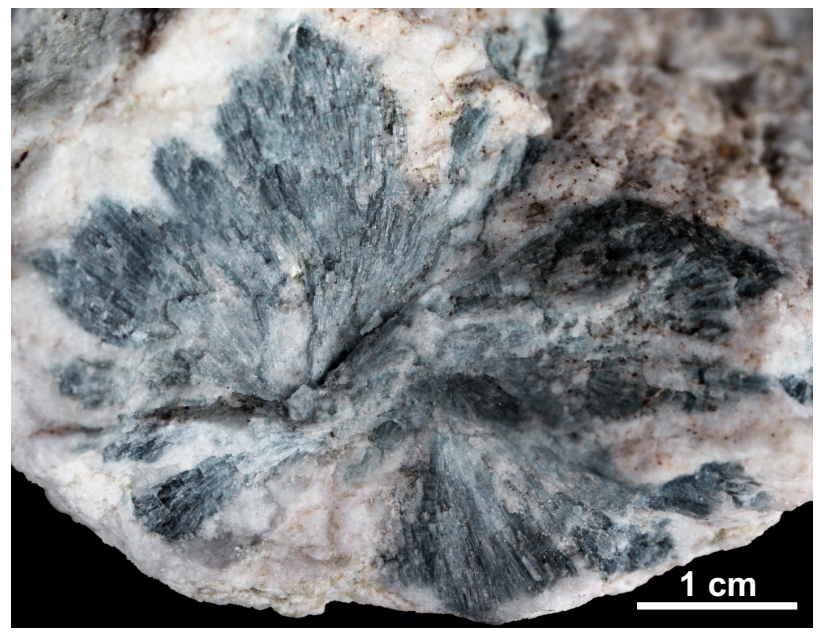

Fig. 1 Radial aggregate of tourmaline crystals from Prosetín.

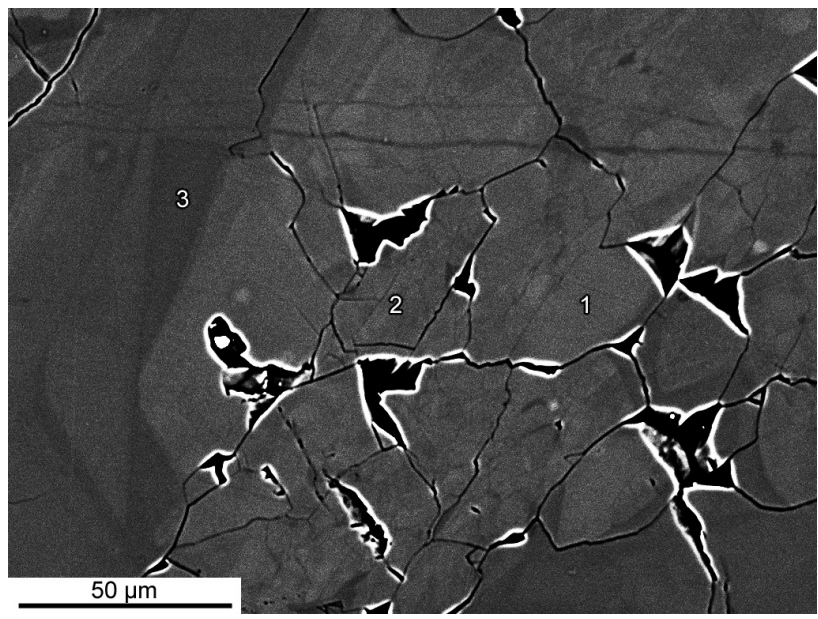

Fig. 2 Back-scattered electron (BSE) image of zoned tourmaline from Prosetín. 1 - zone enriched in $X$-site vacancy; 2 - zone with low $X$-site vacancy and Ca contents - „oxydravite“; 3 - zone enriched in $\mathrm{Ca}$. 
Tab. 1 Representative electron-microprobe analyses of tourmaline from Prosetín (in wt. \% and $a p f u$ )

\begin{tabular}{|c|c|c|c|c|c|c|}
\hline & Phase 1 & Phase 1 & Phase 2 & Phase 2 & Phase 3 & Phase 3 \\
\hline $\mathrm{SiO}_{2}$ & 38.42 & 38.24 & 37.80 & 37.32 & 37.54 & 37.67 \\
\hline $\mathrm{TiO}_{2}^{2}$ & b.d.l. & b.d.l. & b.d.l. & 0.03 & 0.03 & 0.04 \\
\hline $\mathrm{B}_{2} \mathrm{O}_{3}^{*}$ & 10.89 & 10.81 & 10.85 & 10.72 & 10.81 & 10.84 \\
\hline $\mathrm{Al}_{2} \mathrm{O}_{3}$ & 34.33 & 33.81 & 35.56 & 33.99 & 32.79 & 32.90 \\
\hline $\mathrm{FeO}$ & 2.48 & 2.36 & 2.11 & 2.00 & 0.60 & 0.52 \\
\hline $\mathrm{MgO}$ & 8.71 & 8.83 & 8.10 & 9.03 & 11.13 & 11.14 \\
\hline $\mathrm{CaO}$ & 0.13 & 0.17 & 0.39 & 0.98 & 1.66 & 1.62 \\
\hline $\mathrm{Na}_{2} \mathrm{O}$ & 1.62 & 1.61 & 2.34 & 2.18 & 1.84 & 1.72 \\
\hline $\mathrm{K}_{2} \mathrm{O}$ & 0.03 & 0.00 & 0.03 & 0.03 & 0.03 & 0.02 \\
\hline $\mathrm{H}_{2} \mathrm{O} *$ & 3.49 & 3.47 & 3.08 & 3.12 & 3.32 & 3.37 \\
\hline Total & 100.15 & 99.35 & 100.33 & 99.40 & 99.76 & 99.93 \\
\hline $\mathrm{Si}$ & 6.132 & 6.151 & 6.057 & 6.049 & 6.034 & 6.038 \\
\hline $\mathrm{B}$ & 3.000 & 3.000 & 3.000 & 3.000 & 3.000 & 3.000 \\
\hline $\mathrm{Al}$ & 4.962 & 4.964 & 4.958 & 4.964 & 4.963 & 4.963 \\
\hline $\mathrm{Mg}$ & 1.036 & 1.036 & 1.036 & 1.036 & 1.036 & 1.036 \\
\hline$\sum Z$ & 6.000 & 6.000 & 6.000 & 6.000 & 6.000 & 6.000 \\
\hline $\mathrm{Ti}$ & - & - & - & 0.003 & 0.004 & 0.005 \\
\hline $\mathrm{A} 1$ & 1.497 & 1.446 & 1.758 & 1.530 & 1.249 & 1.252 \\
\hline $\mathrm{Fe}$ & 0.332 & 0.317 & 0.283 & 0.271 & 0.081 & 0.070 \\
\hline $\mathrm{Mg}$ & 1.037 & 1.082 & 0.900 & 1.146 & 1.632 & 1.626 \\
\hline$\sum Y$ & 2.868 & 2.849 & 2.943 & 2.951 & 2.966 & 2.962 \\
\hline $\mathrm{Ca}$ & 0.022 & 0.030 & 0.067 & 0.170 & 0.286 & 0.278 \\
\hline $\mathrm{Na}$ & 0.502 & 0.502 & 0.728 & 0.686 & 0.573 & 0.536 \\
\hline K & 0.005 & 0.002 & 0.005 & 0.006 & 0.005 & 0.005 \\
\hline${ }^{x_{\square}}$ & 0.471 & 0.466 & 0.200 & 0.139 & 0.135 & 0.182 \\
\hline $\mathrm{O}$ & 0.277 & 0.275 & 0.703 & 0.628 & 0.441 & 0.397 \\
\hline $\mathrm{OH}$ & 3.720 & 3.725 & 3.295 & 3.370 & 3.559 & 3.603 \\
\hline$\sum V+W$ & 4.000 & 4.000 & 4.000 & 4.000 & 4.000 & 4.000 \\
\hline$\sum$ cations & 18.529 & 18.534 & 18.800 & 18.861 & 18.865 & 18.818 \\
\hline$\sum \mathrm{Al}$ & 6.459 & 6.410 & 6.717 & 6.494 & 6.212 & 6.216 \\
\hline
\end{tabular}

* contents calculated from ideal stoichiometry

b.d.1. = below detection limit; Phases - see Fig. 2
Tab. 2 Powder X-ray diffraction pattern of Prosetín tourmaline

\begin{tabular}{|c|c|c|c|c|c|}
\hline$h$ & $k$ & $l$ & $d_{\text {obs. }}(\AA)$ & I (\%) & $d_{\text {calc. }}(\AA)$ \\
\hline 1 & 1 & 0 & 7.92 & 5 & 7.96 \\
\hline 1 & 0 & 1 & 6.36 & 22 & 6.38 \\
\hline 0 & 2 & 1 & 4.967 & 13 & 4.979 \\
\hline 3 & 0 & 0 & 4.582 & 23 & 4.595 \\
\hline 2 & 1 & 1 & 4.210 & 34 & 4.221 \\
\hline 2 & 2 & 0 & 3.970 & 100 & 3.979 \\
\hline 0 & 1 & 2 & 3.474 & 38 & 3.483 \\
\hline 1 & 3 & 1 & 3.370 & 10 & 3.377 \\
\hline 4 & 0 & 1 & 3.103 & 6 & 3.108 \\
\hline 4 & 1 & 0 & 3.003 & 20 & 3.008 \\
\hline 1 & 2 & 2 & 2.956 & 36 & 2.962 \\
\hline 3 & 2 & 1 & 2.889 & 7 & 2.895 \\
\hline 3 & 1 & 2 & 2.618 & 6 & 2.621 \\
\hline 0 & 5 & 1 & 2.571 & 41 & 2.575 \\
\hline 0 & 0 & 3 & 2.3946 & 9 & 2.3999 \\
\hline 2 & 3 & 2 & 2.3728 & 7 & 2.3758 \\
\hline 5 & 1 & 1 & 2.3378 & 10 & 2.3412 \\
\hline 5 & 0 & 2 & 2.1853 & 5 & 2.1887 \\
\hline 4 & 3 & 1 & 2.1586 & 7 & 2.1616 \\
\hline 0 & 3 & 3 & 2.1240 & 6 & 2.1272 \\
\hline 4 & 2 & 2 & 2.1071 & 5 & 2.1104 \\
\hline 2 & 2 & 3 & 2.0519 & 7 & 2.0551 \\
\hline 1 & 5 & 2 & 2.0370 & 13 & 2.0399 \\
\hline 1 & 6 & 1 & 2.0147 & 5 & 2.0178 \\
\hline 4 & 4 & 0 & 1.9864 & 4 & 1.9896 \\
\hline 3 & 4 & 2 & 1.9157 & 10 & 1.9178 \\
\hline 1 & 4 & 3 & 1.8736 & 4 & 1.8760 \\
\hline 6 & 2 & 1 & 1.8448 & 4 & 1.8475 \\
\hline 3 & 3 & 3 & 1.7770 & 3 & 1.7797 \\
\hline 0 & 6 & 3 & 1.6574 & 5 & 1.6596 \\
\hline 2 & 7 & 1 & 1.6378 & 5 & 1.6397 \\
\hline 4 & 0 & 4 & 1.5943 & 3 & 1.5954 \\
\hline 5 & 5 & 0 & 1.5902 & 8 & 1.5917 \\
\hline 4 & 5 & 2 & 1.5833 & 2 & 1.5847 \\
\hline 4 & 6 & 1 & 1.5428 & 3 & 1.5443 \\
\hline
\end{tabular}

Tab. 3 Lattice parameters and bond lengths of octahedral sites comparing tourmaline from Prosetín with published data

\begin{tabular}{|c|c|c|c|c|c|c|c|c|c|}
\hline Locality & Reference & Mineral & $a[\AA]$ & $c[\AA]$ & $V\left[\AA^{3}\right]$ & $<Y-\mathrm{O}>*[\AA]$ & $<Z-\mathrm{O}>*[\AA]$ & ${ }^{Z} \mathrm{Mg}^{\dagger}(a p f u)$ & Method \\
\hline $\begin{array}{l}\text { Prosetín, Czech } \\
\text { Republic }\end{array}$ & this work & $\begin{array}{l}\text { dravite to } \\
\text { oxy-dravite }\end{array}$ & $15.9116(6)$ & $7.1987(4)$ & $1578.37(8)$ & 1.995 & 1.929 & 1.036 & PXRD \\
\hline $\begin{array}{l}\text { Prosetín, Czech } \\
\text { Republic }\end{array}$ & $\begin{array}{l}\text { Povondra and } \\
\text { Novák (1986) }\end{array}$ & dravite & $15.908(3)$ & $7.192(3)$ & $1576.1(7)$ & 1.992 & 1.927 & 0.934 & PXRD \\
\hline $\begin{array}{l}\text { Gemerská } \\
\text { Poloma, Slovakia }\end{array}$ & $\begin{array}{c}\text { Bačík et al. } \\
\text { (2011a) }\end{array}$ & dravite & $15.9289(7)$ & $7.2132(17)$ & $1584.99(15)$ & 2.007 & 1.934 & 1.256 & PXRD \\
\hline $\begin{array}{l}\text { Forshammar, } \\
\text { Sweden }\end{array}$ & $\begin{array}{l}\text { Bačík et al. } \\
\text { (in print) }\end{array}$ & dravite & $15.9223(6)$ & $7.1706(5)$ & 1574.34 & 2.002 & 1.921 & 0.7 & SREF \\
\hline Bajkal, Russia $^{1}$ & $\begin{array}{l}\text { Bosi and Lucchesi } \\
\text { (2004) }\end{array}$ & oxy-dravite & $15.9030(7)$ & $7.1951(4)$ & 1575.89 & 2.011 & 1.930 & 0.991 & SREF \\
\hline $\begin{array}{l}\text { Small Falls, } \\
\mathrm{USA}^{2}\end{array}$ & $\begin{array}{c}\text { Bloodaxe et al. } \\
\text { (1999) }\end{array}$ & oxy-dravite & $15.945(1)$ & $7.169(1)$ & 1578.58 & 2.018 & 1.920 & 0.635 & SREF \\
\hline $\begin{array}{l}\text { Steinthaller, } \\
\text { Austria }^{3}\end{array}$ & Ertl et al. (2010) & fluor-dravite & $15.9354(4)$ & $7.1934(4)$ & 1581.94 & 2.011 & 1.928 & 0.75 & SREF \\
\hline $\begin{array}{l}\text { Kyonosawa, } \\
\text { Japan }\end{array}$ & $\begin{array}{l}\text { Hawthorne et al. } \\
\text { (1999) }\end{array}$ & magnesio-foitite & $15.884(4)$ & $7.178(3)$ & $1568.0(6)$ & 1.976 & 1.923 & - & SREF \\
\hline
\end{tabular}

${ }^{1}$ sample 9840f; ${ }^{2}$ sample Ru-T18-92; ${ }^{3}$ sample STE; lattice parameters from PXRD - powder XRD, SREF - structure refinement;

* - bond lengths calculated according to empirical formulae by Bosi and Lucchesi (2004); ${ }^{\dagger} \mathrm{Mg}$ obtained by the empirical formula of Ertl et al. (2010). 


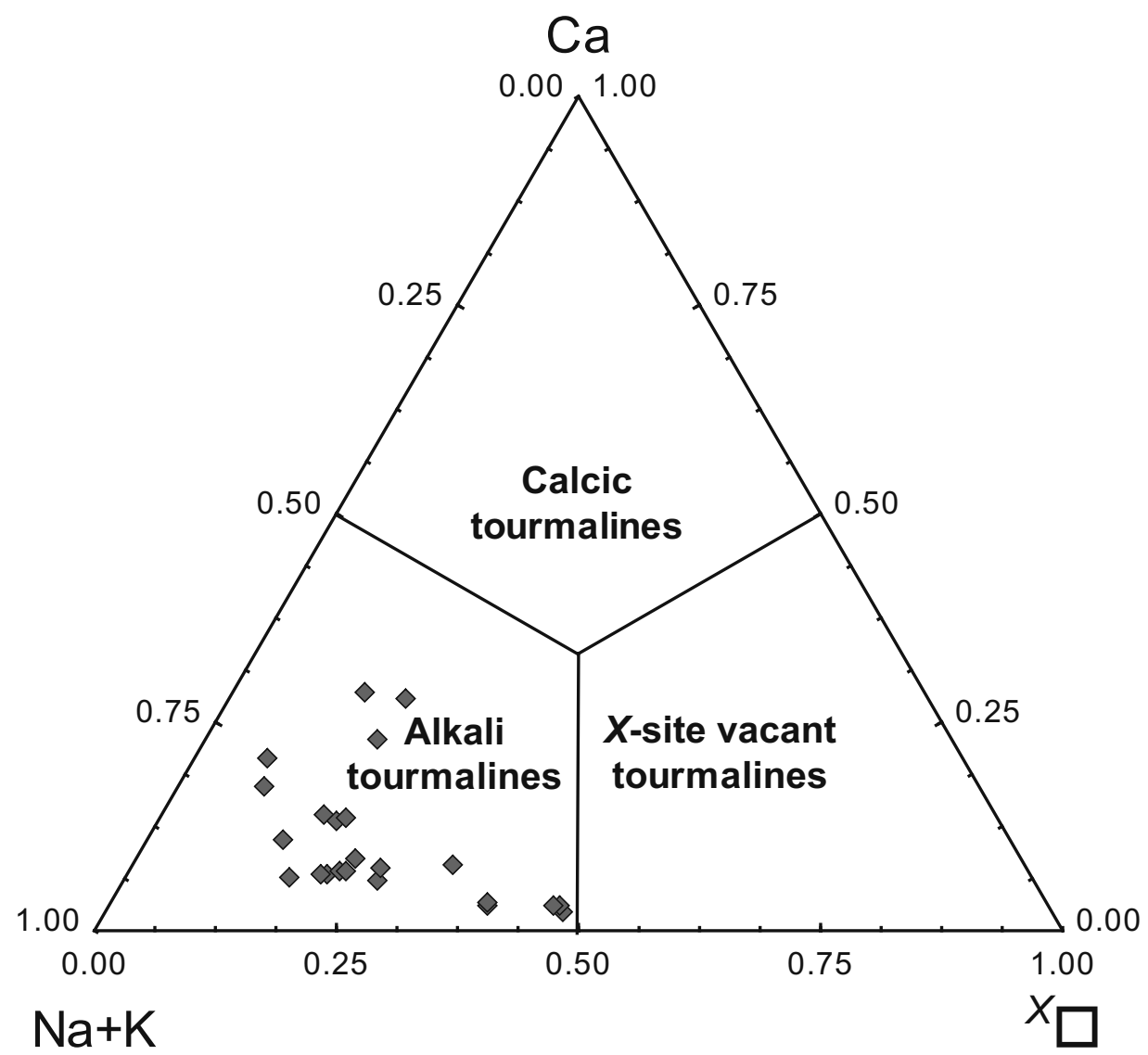

Fig. 3 - Classification diagram $(\mathrm{Na}+\mathrm{K})-\mathrm{Ca}-{ }^{X_{\square}}$ for minerals of tourmaline supergroup.

\section{$\mathrm{Na}+\mathrm{K}$}

low to balance charge excess sufficiently. In contrast, the increase in the Al correlates with the ${ }^{W} \mathrm{O}$ contents calculated from the charge-balanced formula (Tab. 1). This suggests a strong influence of the $\mathrm{AlO}(\mathrm{MgOH})_{-1}$ substitution.

Powder XRD data (Tables 2 and 3) are strongly influenced by the compositional variations of the studied tourmaline. However, based on BSE observations and EMPA study, oxy-dravite and magnesio-foitite phases are dominant and they differ only slightly in $\mathrm{Al}$ and $\mathrm{Mg}$ contents (Tab. 1). Average bond lengths in octahedral sites calculated from lattice parameters were compared to published data; the mean $<Y-\mathrm{O}>$ bond length in the studied tourmaline is shorter than those published for dravite, "oxy-dravite" and fluor-dravite, but longer than in magnesio-foitite (Tab. 3). This corresponds well with the higher contents of $\mathrm{Al}$ in the $Y$ site. In contrast, the $<\mathrm{Z}$-O $>$ bond is relatively long, which could suggest a significant proportion of $\mathrm{Mg}^{2+}$ with higher ionic radius than $\mathrm{Al}^{3+}$ in the octahedral coordination $(0.72$ and 0.535 A, respectively; Shannon 1976).

Tourmaline from Prosetín is relatively poor in trace elements. Only Ti, Sr, and Ga attain more than 100 ppm, the contents of $\mathrm{Sc}, \mathrm{Mn}, \mathrm{Ni}, \mathrm{Zn}$ and $\mathrm{Sn}$ vary between 10 and $100 \mathrm{ppm}$ (Tab. 4). The REE contents are even lower; only $\mathrm{La}, \mathrm{Ce}, \mathrm{Nd}$ and $\mathrm{Y}$ exceed their respective detection limits. There is an apparent correlation of $\mathrm{Ti}$ and $\mathrm{Sr}$ with $\mathrm{Ca}$ (Fig. 6), which suggests that the former two elements are accumulated in Ca-enriched zones of dravite.

Tab. 4 Contents of trace elements (ppm) in Prosetín tourmaline - analyzed by LA-ICP-MS

\begin{tabular}{lcrc}
\hline in ppm & Minimum & Maximum & Limit of detection \\
\hline $\mathrm{Ca}$ & 2400 & 10500 & 1700 \\
$\mathrm{Sc}$ & 13 & 36 & 11 \\
$\mathrm{Ti}$ & 24 & 470 & 13 \\
$\mathrm{~V}$ & $<1$ & 7 & 1 \\
$\mathrm{Mn}$ & 22 & 60 & 8 \\
$\mathrm{Co}$ & 2 & 7 & 0.9 \\
$\mathrm{Ni}$ & 5 & 23 & 5 \\
$\mathrm{Zn}$ & 17 & 45 & 4 \\
$\mathrm{Ga}$ & 73 & 122 & 0.5 \\
$\mathrm{Sr}$ & 95 & 337 & 1 \\
$\mathrm{Y}$ & $<0.01$ & 3 & 0.01 \\
$\mathrm{Sn}$ & 9 & 22 & 6 \\
$\mathrm{La}$ & $<0.1$ & 2 & 0.1 \\
$\mathrm{Ce}$ & 1 & 4 & 0.1 \\
$\mathrm{Nd}$ & $<0.01$ & 4 & $<0.01$ \\
\hline
\end{tabular}




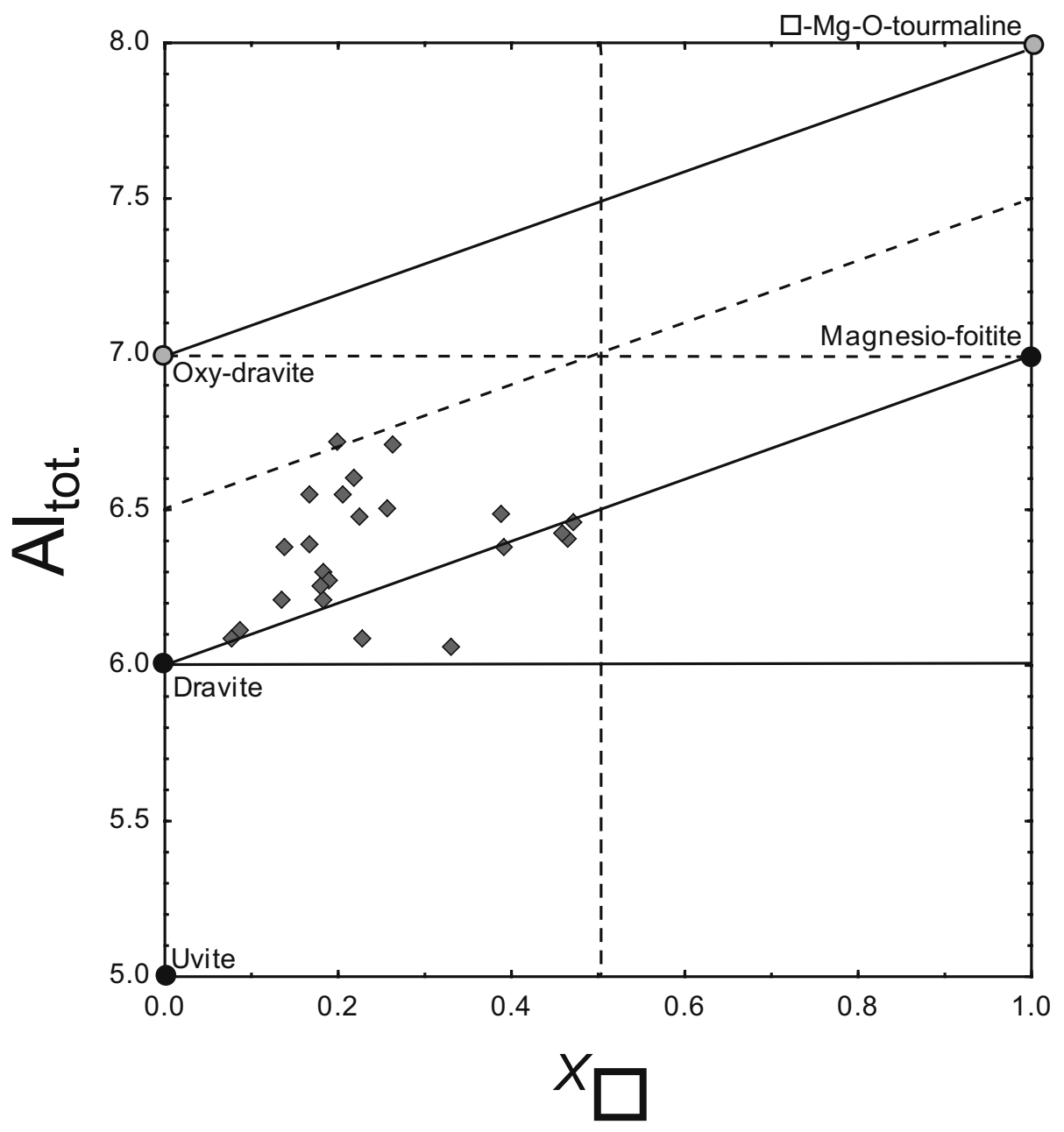

Fig. 4 - Diagram Al vs. ${ }_{\square}$ with end-members of the tourmaline supergroup and substitution trends.

\section{Discussion and conclusions}

\subsection{Crystal chemistry of tourmaline}

Calculation of bond lengths in octahedral sites on a basis of empirical formulae from lattice parameters is appropriate method if no structure-refinement data are available. Besides giving partial information on the structure geometry, it also helps to solve problems with site occupancy and crystal chemistry of mineral. Site occupancy and cation distribution has many effects not only on the geometry of $Y$ and $Z$ octahedra but on the entire structure of tourmaline. Octahedral dimensions influence lattice parameters; the parameter $a$ correlates with $<Y$-O $>$ bond length, whereas $c$ is correlated with the $\langle Z$-O $>$ bond length (Bosi and Lucchesi 2004). The $<Z-\mathrm{O}>$ bond length in octahedra entirely occupied by $\mathrm{Al}$, as in elbaite, rossmanite, olenite and foitite, varies between 1.90 and $1.91 \AA$ (e.g., Grice and Ercit 1993; MacDonald et al. 1993; Burns et al. 1994; Selway et al. 1998, Cempírek et al. 2006). In contrast, the $<Z$-O $>$ bond length in $\mathrm{Mg}$-bearing tourmalines is in the range of 1.92 to $1.93 \AA$ (e.g., Bloodaxe et al. 1999; Hawthorne et al. 1999; Bosi and Lucchesi 2004; Ertl et al. 2010; Bačík et al. 2011a, in print). There is a good correlation between ${ }^{Z} \mathrm{Mg}$ content and the $<Z-\mathrm{O}>$ bond length (Ertl et al. 2010): the $\langle Z-O>$ bond length increases with the ${ }^{z} \mathrm{Mg}$ (or other cations with ionic radius larger than $\mathrm{Al}$, if present). Significant amounts of $\mathrm{Mg}$ may enter the $Z$ site due to $\mathrm{Al}-\mathrm{Mg}$ disorder even if the $\mathrm{Al}$ content exceeds $6 a p f u$ and could be sufficient to fill the $Z$ site entirely (e.g., Grice and Ercit 1993; Hawthorne et al. 1993, 1999; Bloodaxe et al. 1999; Bosi and Lucchesi 2004; Ertl et al. 2010). The studied tourmalines have affinity to magnesio-foitite and oxy-dravite with a relatively high value of the $<Z$-O $>$ bond length $(1.929$ $\AA$ ), despite of their Al-rich composition (up to $6.72 \mathrm{Al}$ apfu). Therefore, the total amount of Al is not a key factor determining the $Z$-site occupancy in $\mathrm{Mg}$-bearing tourmalines. The disorder of $\mathrm{Al}$ and $\mathrm{Mg}$ among the octahedral sites is controlled by different mechanisms, due to short-range bond-valence requirements (e.g. Hawthorne 2002); in any case, it is reflected by the $W$-site occupancy. If the $W$ site is fully occupied by $\mathrm{OH}$, only $3^{Y} \mathrm{R}^{2+}$ or $2^{Y} \mathrm{R}^{2+}+{ }^{Y} \mathrm{R}^{3+}$ cation structural arrangements are stable, in contrast to the $3{ }^{Y} \mathrm{R}^{3+}$ or $2^{Y} \mathrm{R}^{3+}+{ }^{Y} \mathrm{R}^{2+}$ 
cation arrangements which are found in ${ }^{\mathrm{W}} \mathrm{O}^{2-}$-dominant "oxy-tourmalines" (Hawthorne 2002). Calculated ${ }^{W} \mathrm{O}$ proportion therefore suggests relatively large degree of $\mathrm{Al}-\mathrm{Mg}$ disorder in the studied samples, at least in the oxy-dravite compositions. Significant role of deprotonized $\mathrm{O}$ in the $W$ site of the Prosetín tourmaline was also confirmed by wet chemical analysis $\left({ }^{V+W} \mathrm{OH}\right.$ $=3.68 p f u$ ) of Povondra and Novák (1986). On the other hand, since the disorder is commonly present in $(\mathrm{OH}, \mathrm{F})$-dominant tourmalines, the disorder-controlling factor must be the thermodynamic stability of the $Y, Z$ site configuration within the specific tourmaline composition. Good examples include the magnesio-foitite from Kyonosawa, Japan (Hawthorne et al. 1999), and fluor-dravite from Steinthaller, Austria (Ertl et al. 2010) which lack ${ }^{W} \mathrm{O}$ but they seem to be medium to strongly disordered. Possible factors for $Y$ site contents and Al-Mg disorder discussed in the literature include $X$ site contents (e.g. Ertl et al. 2010), $\mathrm{Fe} /(\mathrm{Fe}+\mathrm{Mg}$ ) ratio (Grice and Ercit 1993), structure deformations (Foit 1989; Bosi and Lucchesi 2007) or temperature (Ertl et al. 2008; Bosi 2011). Besides a minor Ca-content (uvite component), the high amount of $X$-site vacancies plays a significant role in ${ }^{W} \mathrm{O}$-poor dravite-magnesio-foitite phase of the Prosetín tourmaline.

The size of $Y$ octahedron depends on the synergic effect of the various cations occupying the site. This is a net result of an interplay between the size contraction owing to the presence of smaller cations $\left({ }^{Y} \mathrm{Al}^{3+},{ }^{Y} \mathrm{Li}^{+}\right)$ and size-expansion caused by ${ }^{\gamma} \mathrm{Fe}^{2+},{ }^{Y} \mathrm{Mg}^{2+}$, and ${ }^{Y} \mathrm{~V}^{3+}$ with larger ionic radii (Bosi and Lucchesi 2004). The $<Y$-O $>$ bond length may decrease to $1.96 \AA$ in olenite with $Y$ site dominated by $\mathrm{Al}$ (Hughes et al. 2000), 2.00 $\AA$ in elbaite with $Y$ site occupied by $\mathrm{Al}$ and Li (Burns et al. 1994; Bosi et al. 2005), and $1.98 \AA$ in magnesiofoitite with ${ }^{Y} \mathrm{Mg}$ and ${ }^{Y} \mathrm{Al}$ (Hawthorne et al. 1999). On the other hand, this parameter increases to $2.05 \AA$ in ${ }^{\gamma} \mathrm{Fe}^{2+}$-dominant schorl (Grice and Ercit 1993; Bloodaxe et al. 1999; Bosi and Lucchesi 2004). The typical value of the $<Y$-O $>$ bond length in ${ }^{Y} \mathrm{Mg}$-dominant dravitic-"oxydravitic" tourmalines varies between 2.00 and $2.01 \AA$ (Bloodaxe et al. 1999; Bosi and Lucchesi 2004; Ertl et al. 2010; Bačík et al. 2011a, in print). Thus, lower value of the $\langle Y-\mathrm{O}\rangle$ bond length in Prosetín relative to other dravitic tourmalines is obviously the cumulative effect of very low $\mathrm{Fe}^{2+}$ and relatively high ${ }^{Y} \mathrm{Al}$ contents owing to: (1) $\mathrm{AlO}(\mathrm{MgOH})_{-1}$ substitution mostly in the "oxydravite" phase; (2) ${ }^{X_{\square}} \mathrm{Al}(\mathrm{NaMg})_{-1}$ substitution mostly in the dravite-magnesio-foitite phase and (3) extensive Al-Mg disorder which even more enriches the $Y$ site in $\mathrm{Al}$ and decreases the ${ }^{Y} \mathrm{Mg}$ content.

Dravite from Prosetín has blue-grey color which is typical especially of Li-bearing and rather less frequent in Mg-dominant tourmalines. Similar blue dravite was
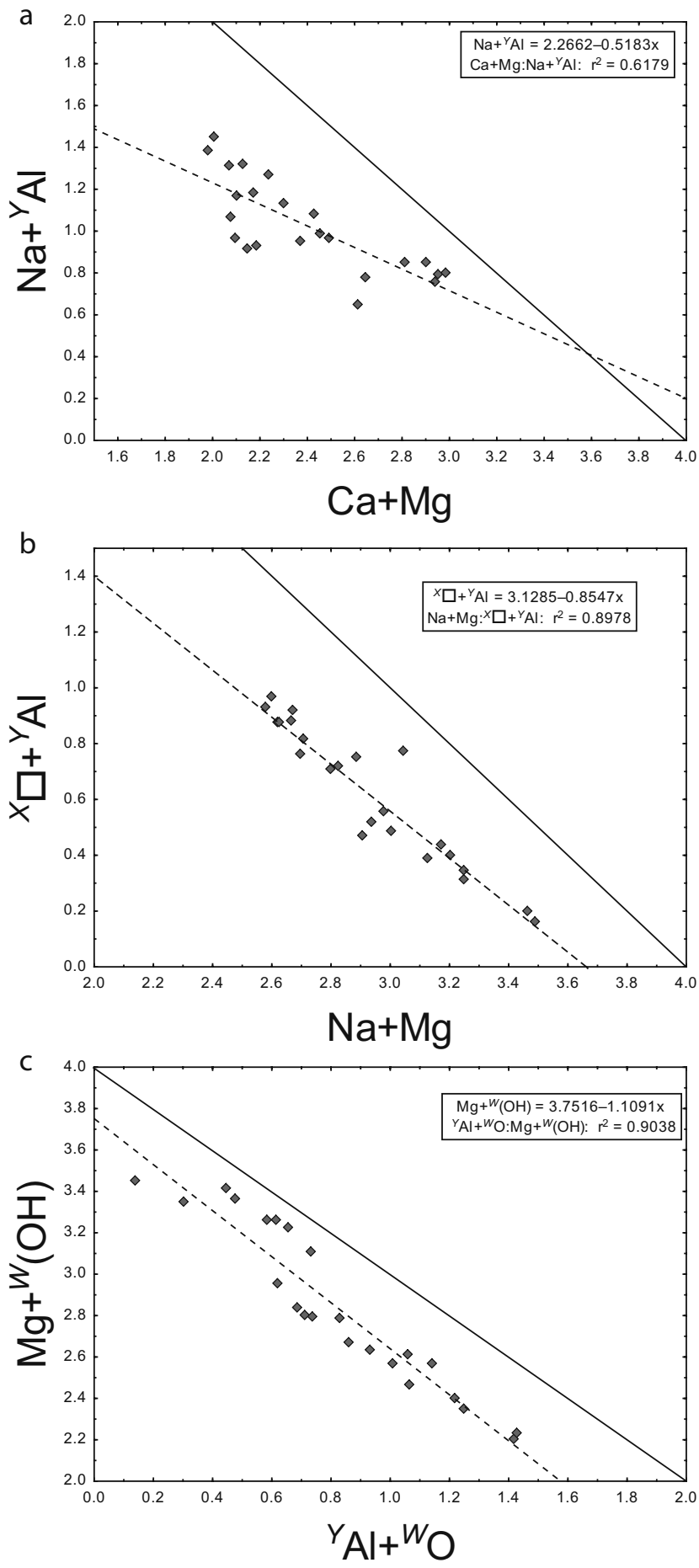

Fig. 5 Substitution diagrams of tourmaline from Prosetín: a - substitution $\mathrm{CaMg}\left(\mathrm{Na}^{Y} \mathrm{Al}\right)_{-1} ; \mathbf{b}$ - substitution $\mathrm{NaMg}\left({ }^{X} \square^{Y} \mathrm{Al}\right)_{-1} ; \mathbf{c}$ - substitution ${ }^{\gamma} \mathrm{Al}^{W} \mathrm{O}\left(\mathrm{Mg}^{W} \mathrm{OH}\right)$. Solid line represents ideal correlation, dashed line is the best linear fit to the data.

also described from several localities of Li-poor granitic pegmatites and marbles in the Moldanubicum, Czech Republic (Povondra 1981; Novák 1998) and also from Szkłary pegmatite, Poland (Pieczka 2007). It has been shown that the blue color in tourmaline is related to the 

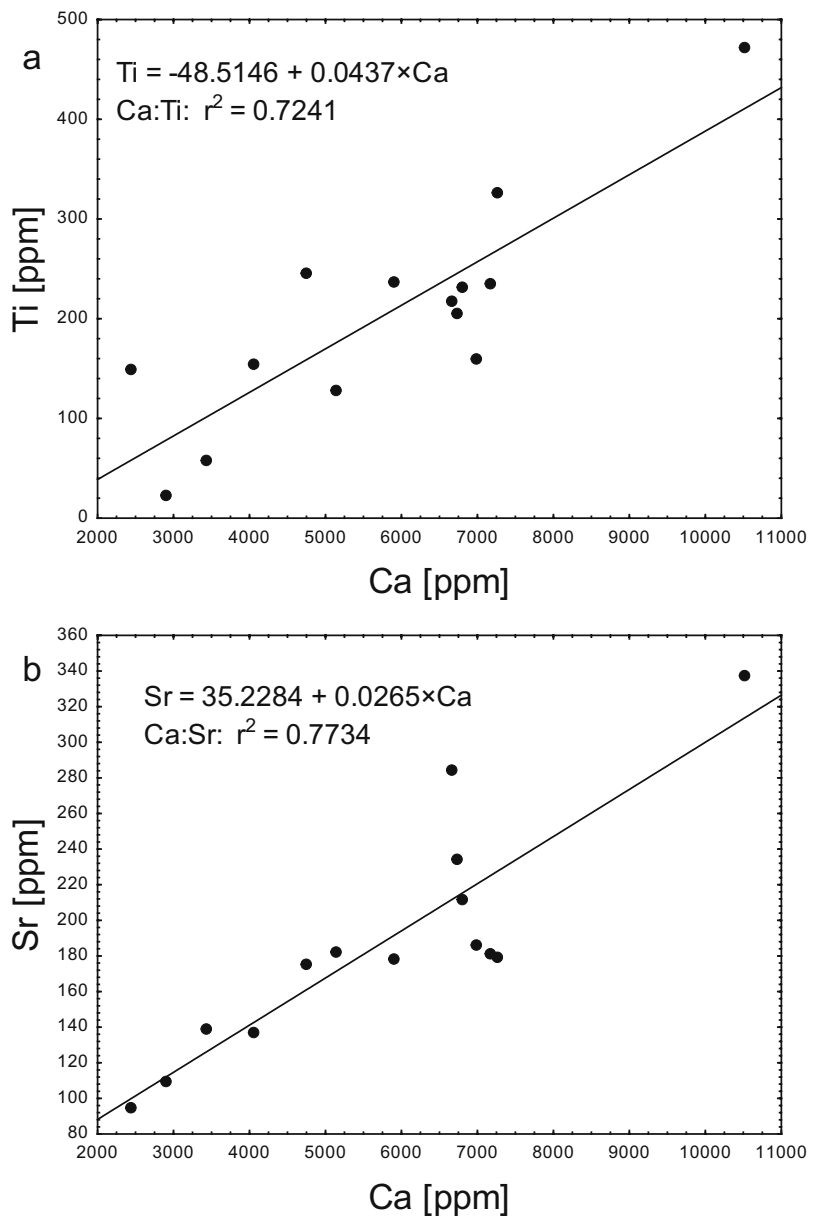

Fig. 6 Binary diagrams of trace elements in Prosetín tourmaline (LA-ICP-MS data in ppm): a - Ti vs. Ca; b - Sr vs. Ca. Solid line represents the best linear fit to the data.

spin-allowed crystal field transitions of $\mathrm{Fe}^{2+}$ in deformed octahedral sites while usual inter-valence charge transfer transitions $\left(\mathrm{Fe}^{2+}-\mathrm{Ti}^{4+}, \mathrm{Fe}^{2+}-\mathrm{Fe}^{3+}\right)$ are responsible for brown and red-brown colors (e.g., Mattson and Rossman 1987; Cempírek et al. 2006; da Fonseca-Zang et al. 2008). High $\mathrm{Fe}^{3+}$ and $\mathrm{Ti}^{4+}$ contents cause dark (macroscopically black) color of Fe-rich tourmalines (e.g., Pieczka 2007; da Fonseca-Zang et al. 2008). All three tourmaline types from Prosetín are extremely Ti poor but contain significant amounts of $\mathrm{Fe}^{2+}$. Hence their blue-grey color is most likely a result of $\mathrm{Fe}^{2+}$ crystal field transitions along with the presence of only limited amounts of other chromophores.

\subsection{Origin of tourmaline and plagioclase- muscovite-scapolite rocks}

The tourmaline composition, including trace elements, can be efficiently used to mark its genetic environment. The fibrous form of the Prosetín tourmaline and its low $\mathrm{Ca}$ content indicates fast non-equilibrium crystalliza- tion from Na-rich fluid, along with low degree of in situ contamination. The zoning pattern with $X$-site vacant tourmaline core and dravitic rim resembles tourmalines grown in the prograde metamorphic environment (e.g., Henry and Dutrow 1996; Bačík et al. 2011b; Gieré et al. 2011). In contrast, tourmalines in granitic pegmatites usually display reverse zoning with rimward decrease in $\mathrm{Ti}$ and $\mathrm{Mg}$ and increase in $\mathrm{Al}$ and $X$-site vacancy, which indicate decreasing temperature and increasing degree of fractionation of the melt (e.g., Jolliff et al. 1987; Selway et al. 1999, 2000). Moreover, similar oxy-dravite to povondraite solid solution is typical of the metaevaporitic environment (Henry et al. 1999, 2008; Žáček et al. 2000; Bačík et al. 2008).

Contents of trace elements in tourmaline from Prosetín are relatively low, including the most abundant Ti, $\mathrm{Sr}$ and $\mathrm{Ga}$ (Tab. 4). Clearly, similar effective ionic radii of $\mathrm{Ga}^{3+}$ and $\mathrm{Al}^{3+}$ in octahedral and tetrahedral coordination (Shannon 1976) enable their mutual substitution in $Y$-, $Z$ - and $T$-site positions of the tourmaline structure. Such a relationship between $\mathrm{Al}$ and $\mathrm{Ga}$ was observed also in tourmalines where Ga may attain tens to hundreds of ppm (e.g., Roda-Robles et al. 2004; Novák et al. 2011; Bačík et al. in print). Increased content of Sr can be related to the host-rock environment; $\mathrm{Sr}$ is one of the most abundant elements in seawater, c. $8 \mathrm{ppm}$ (Faure 1977) which could support evaporitic origin of plagioclase-muscovite-scapolite rocks in Prosetín. The concentrations of other trace elements in the studied tourmalines, such as $\mathrm{Mn}, \mathrm{Zn}, \mathrm{Sn}$ and $\mathrm{Li}$, are markedly lower compared to those reported from pegmatite tourmalines (e.g., Hellingwerf et al. 1994; Keller et al. 1999; Roda-Robles et al. 2004; Ertl et al. 2006; Novák et al. 2011; Bačík et al. in print).

The form of occurrence, major- and trace-element compositions of the Prosetín magnesian tourmaline imply rather non-magmatic (i.e., not aplitic or pegmatitic) origin. The new data support the idea of metaevaporitic source of the muscovite-plagioclase-scapolite rocks and formation of the magnesian tourmaline towards the end of the prograde metamorphic phase, as suggested by Opletal et al. (2007). Since the abundance of Cl- and B-rich minerals (scapolite and tourmaline) in some Moldanubian marbles and in associated metapelitic rocks points to their metaevaporitic origin (Kř́bek et al. 1997; Houzar and Novák 2002), further detailed research of tourmaline crystal chemistry is desirable to improve our understanding of its behavior in metacarbonate systems.

Acknowledgements. Authors thank Daniel Ozdín for assistance with the electron-microprobe analysis. Authors are indebted to Milan Novák for editorial handling and also Andreas Ertl with Adam Pieczka for their detailed reviews and very useful suggestions. This work was sup- 
ported by the Slovak Research and Development Agency under contracts VVCE-0033-07, APVV-0557-06, APVV0081-10, VEGA-1/0255/11 and VEGA 1/0670/12 (to PB and PU) and projects GAP210/10/0743 (to JC) and CEITEC (CZ.1.05/1.1.00/02.0068) (to TV).

\section{References}

BAČík P, Uher P, SÝkora M, Lipka J (2008) Low-Al tourmalines of the schorl-dravite-povondraite series in redeposited tourmalinites from the Western Carpathians, Slovakia. Canad Mineral 46: 1117-1129

BAČík P, DiAnišKa I, ŠTeVko M, SEČKÁR P (2011a) Brown finely acicular dravite from talc-magnesite deposit Gemerská Poloma (Gemeric Superunit, Slovakia). Bull mineral-petrolog Odd Nár Muz (Praha) 19: 164-167 (in Slovak)

BAČík P, Méres Š, Uher P (2011b) Vanadium-bearing tourmaline in metacherts from Chvojnica, Slovak Republic: crystal chemistry and multi-stage evolution. Canad Mineral 49: 195-206

Bačík P, Uher P, Ertl A, Jonsson E, Nysten P, Kanický $\mathrm{V}$, VACUlOvič T (in print) Zoned REE-enriched dravite from a granitic pegmatite in Forshammar, Bergslagen Province, Sweden: EMPA, XRD and LA-ICP-MS study. Canad Mineral 50.

Bloodaxe ES, Hughes JM, Dyar MD, Grew ES, Guidotti CV (1999) Linking structure and chemistry in the schorldravite series. Amer Miner 84: 922-928

Bosi F (2011) Stereochemical constraints in tourmaline: from a short-range to a long-range structure. Canad Mineral 49:17-27

Bosi F, Lucchesi S (2004) Crystal chemistry of the schorldravite series. Eur J Mineral 16: 335-344

Bosi F, Lucchesi S (2007) Crystal chemical relationships in the tourmaline group: structural constraints on chemical variability. Amer Miner 92: 1054-1063

Bosi F, Andreozzi GB, Federico M, Graziani G, Lucchesi S (2005) Crystal chemistry of the elbaite-schorl series. Amer Miner 90: 1784-1792

Burns PC, MacDonald DJ, Hawthorne FC (1994) The crystal chemistry of manganese-bearing elbaite. Canad Mineral 32: 31-41

Cempírek J, Novák M, Ertl A, Hughes JM, Rossman GR, DYAR MD (2006) Fe-bearing olenite with tetrahedrally coordinated Al from an abyssal pegmatite of the Bohemian Massif at Kutná Hora: structure, crystal chemistry, and optical spectra. Canad Mineral 44: 23-30

DA Fonseca-ZAng WA, ZANG JW, Hofmeister W (2008) The Ti-influence on the tourmaline colour. J Brazil Chem Soc 19: 1186-1192

Ertl A, Hughes JM, Prowatke S, Ludwig T, Prasad PSR, Brandstätter F, Körner W, Schuster R, Pertlik F,
Marschall H (2006) Tetrahedrally coordinated boron in tourmalines from the liddicoatite-elbaite series from Madagascar: structure, chemistry, and infrared spectroscopic studies. Amer Miner 91: 1847-1856

Ertl A, Rossman GR, Hughes JM, Ma C, Brandstätter F (2008) $\mathrm{V}^{3+}$-bearing, Mg-rich, strongly disordered olenite from a graphite deposit near Amstall, Lower Austria: a structural, chemical and spectroscopic investigation. Neu Jb Mineral, Abh 184: 243-253

Ertl A, Mali H, Schuster R, Körner W, Hughes JM, BrandstÄtter F, Tillmanns E (2010) Li-bearing, disordered $\mathrm{Mg}$-rich tourmaline from a pegmatite-marble contact in the Austroalpine basement units (Styria, Austria). Mineral Petrol 99: 89-104

FAure G (1977) Principles of Isotope Geology. John Wiley \& Sons, New York, pp 1-464

Finger F, Gerdes A, Janoušek V, René M, Riegler G (2007) Resolving the Variscan evolution of the Moldanubian sector of the Bohemian Massif: the significance of the Bavarian and the Moravo-Moldanubian tectonometamorphic phases. J Geosci 52: 9-28

FOIT JR FF (1989) Crystal chemistry of alkali-deficient schorl and tourmaline structural relationships. Amer Miner 74: 422-431

Gieré R, Rumble D, Günther D, Connolly J, Caddick MJ (2011) Correlation of growth and breakdown of major and accessory minerals in metapelites from Campolungo, Central Alps. J Petrol 52: 2293-2334

Grice JD, ERcit TS (1993) Ordering of Fe and $\mathrm{Mg}$ in tourmaline: the correct formula. Neu Jb Mineral, Abh 165: $245-266$

Hawthorne FC (2002) Bond-valence constraints on the chemical composition of tourmaline. Canad Mineral 40: 789-797

Hawthorne FC, MacDonald DJ, Burns PC (1993) Reassignment of cation site occupancies in tourmaline: $\mathrm{Al}-\mathrm{Mg}$ disorder in the crystal structure of dravite. Amer Miner 78: 265-270

Hawthorne FC, Selway JB, Kato A, Matsubara S, Shimizu M, GRICE JD, VAJDAK J (1999) Magnesiofoitite, $\square\left(\mathrm{Mg}_{2} \mathrm{Al}\right)$ $\mathrm{Al}_{6}\left(\mathrm{Si}_{6} \mathrm{O}_{18}\right)\left(\mathrm{BO}_{3}\right)_{3}(\mathrm{OH})_{4}$, a new alkali-deficient tourmaline. Canad Miner 37: 1439-1443

Hellingwerf RH, Gatedal K, Gallagher V, Baker JH (1994) Tourmaline in the central Swedish ore district. Miner Depos 29: 189-205

Henry DJ, Dutrow BL (1996) Metamorphic tourmaline and its petrologic applications. In: GREw ES, ANOwITz LM (eds) Boron. Mineralogy, Petrology and Geochemistry. Mineralogical Society of America and Geochemical Society Reviews in Mineralogy and Geochemistry 33: 503-557

Henry DJ, GuidotTi CV (1985) Tourmaline as a petrogenetic indicator mineral: an example from the staurolite-grade metapelites of NW Maine. Amer Miner 70: 1-15 
Henry DJ, Kirkland BL, Kirkland DW (1999) Sector zoned tourmaline from the cap rock of a salt dome. Eur J Mineral 11: 263-280

Henry DJ, Sun H, Slack J, Dutrow BL (2008) Tourmaline in meta-evaporites and highly magnesian rocks: perspectives from Namibian tourmalinites. Eur J Mineral 20: 889-904

Houzar S, Leichmann J (2003) Application of cathodoluminescence to the study of metamorphic textures in marbles from the eastern part of the Bohemian Massif. Bull Geosci 78: 241-250

Houzar S, NovÁk M (2002) Marbles with carbonatite-like geochemical signature from variegated units of the Bohemian Massif, Czech Republic, and their geological significance. J Czech Geol Soc 47: 103-109

Houzar S, NĚMečKová M, NovÁk M (2000) A report on research of tremolite marbles at Kuroslepy in west Moravia (Olešnice Group, Moravicum). Geol Výzk Mor Slez 1999: 120-122 (in Czech)

Hughes JM, Ertl A, Dyar MD, Grew ES, Shearer CK, Yates MG, Guidotti CV (2000) Tetrahedrally coordinated boron in a tourmaline: boron-rich olenite from Stoffhütte, Koralpe, Austria. Canad Miner 38: 861-869

Jolliff BL, Papike JJ, Laul JC (1987) Mineral recorders of pegmatite internal evolution: REE contents of tourmaline from the Bob Ingersoll pegmatite, South Dakota. Geochim Cosmochim Acta 51: 2225-2232

Kalvoda J, Bábek O, Fatka O, Leichmann J, Melichar R, Nehyba S, ŠPAČEK P (2008) Brunovistulian Terrane (Bohemian Massif, Central Europe) from late Proterozoic to late Paleozoic: a review. Int J Earth Sci (Geol Rundsch) 97: 497-518

Keller P, Roda Robles E, Pesquera Pérez A, Fontan F (1999) Chemistry, paragenesis and significance of tourmaline in pegmatites of the Southern Tin Belt, central Namibia. Chem Geol 158: 203-225

Kř́íbeK B, Hladíková J, Frýda J (1997) Scapolite and anhydrite-bearing rocks from the Moldanubian zone of the Bohemian Massif: Metamorphosed exhalites and evaporites. J Czech Geol Soc 42: 62

MacDonald DJ, Hawthorne FC, Grice JD (1993) Foitite, $\square\left[\mathrm{Fe}_{2}^{2+}\left(\mathrm{Al}_{2}, \mathrm{Fe}^{3+}\right)\right] \mathrm{Al}_{6} \mathrm{Si}_{6} \mathrm{O}_{18}\left(\mathrm{BO}_{3}\right)_{3}(\mathrm{OH})_{4}$, a new alkalideficient tourmaline: description and crystal structure. Amer Miner 78: 1299-1303

MATTSON SM, Rossman GR (1987) Identifying characteristics of charge transfer transitions in minerals. Phys Chem Miner 14: 94-99

Neubauer F, Handler R (2000) Variscan orogeny in the Eastern Alps and Bohemian Massif: how do these units correlate? Mitt Österr Geol Ges 92: 35-59

NovÁk M (1998) Blue dravite as an indicator of fluid composition during subsolidus replacement processes in Li-poor granitic pegmatites in the Moldanubicum, Czech Republic. J Czech Geol Soc 43: 24-30
Novák M, Škoda R, Filip J, Macek I, Vaculovič T (2011) Compositional trends in tourmaline from intragranitic NYF pegmatites of the Třebíč Pluton, Czech Republic: an electron microprobe, Mössbauer and LA-ICP-MS study. Canad Mineral 49: 359-380

Opletal V (2009) Metamorphic evolution of carbonate-evaporitic sedimentary complex in the Vranov-Olešnice Group of the Moravicum. Unpublished Thesis, Faculty of Natural Science, Masaryk University, Brno, pp 1-67 (in Czech)

Opletal V, Houzar S, Leichmann J (2007) Muscoviteplagioclase layers in dolomite marble near Prosetín (Olešnice Unit, Moravicum) concordant injections of aplite or metaevaporites? Acta Mus Moraviae, Sci Geol 92: 131-142 (in Czech)

PIECZKA A (2007) Blue dravite from the Szkłary pegmatite (Lower Silesia, Poland). Mineralogia 38: 209-218

Pouchou JL, Pichoir F (1985) “PAP” ( $\varphi \rho Z)$ procedure for improved quantitative microanalysis. In: ARMSTRONG JT (ed) Microbeam Analysis. San Francisco Press, San Francisco, pp 104-106

Povondra P (1981) Crystal chemistry of tourmalines of the schorl-dravite series. Acta Univ Carol, Geol 3: 223-264

Povondra P, NovÁk M (1986) Tourmalines in metamorphosed carbonate rock from western Moravia, Czechoslovakia. Neu Jb Mineral, Mh 1986: 273-282

Roda-Robles E, Pesquera A, Gil PP, Torres-Ruiz J, FonTAN F (2004) Tourmaline from the rare-element Pinilla pegmatite (Central Iberian Zone, Zamora, Spain): chemical variation and implications for pegmatitic evolution. Mineral Petrol 81: 249-263

Schulmann K, Ledru P, Autran A, Melka R, Lardeaux JM, Urban M, LobKowicz M (1991) Evolution of nappes in the eastern margin of the Bohemian Massif: a kinematic interpretation. Geol Rundsch 80: 73-92

Schulmann K, Lexa O, Štípská P, Racek M, Tajčmanová L, Konopásek J, Edel JB, Peschler A, Lehmann J (2008) Vertical extrusion and horizontal channel flow of orogenic lower crust: key exhumation mechanism in large hot orogens? J Metamorph Geol 26: 273-297

SEKAnina J (1965a) Minerals and their genetic relationships to rocks in area of geological map 1:50 000, part M 33-93-B (Bystřice nad Pernštejnem). Unpublished Manuscript, Department of Mineralogy and Petrology, Moravian Museum, Brno, pp 1-171 (in Czech)

SEKANINA J (1965b) Vermiculit am Kontakt zwischen Aplit und Dolomit bei Prosetín (Nordteil der Schwarzawakuppel). Acta Univ Carol, Geol 2: 17-30

Selway JB, Novák M, Hawthorne FC, Černý P, Ottolini L, Kyser TK (1998) Rossmanite, $\square\left(\mathrm{LiAl}_{2}\right) \mathrm{Al}_{6}\left(\mathrm{Si}_{6} \mathrm{O}_{18}\right)$ $\left(\mathrm{BO}_{3}\right)_{3}(\mathrm{OH})_{4}$, a new alkali-deficient tourmaline: description and crystal structure. Amer Miner 83: 896-900

Selway, JB, Novák M, Černý P, Hawthorne FC (1999) Compositional evolution of tourmaline in lepidolitesubtype pegmatites. Eur J Mineral 11: 569-584 
Selway JB, Černý P, Hawthorne FC, Novák M (2000) The Tanco pegmatite at Bernic Lake, Manitoba. Canad Mineral 38: 877-891

SHABYNIN LI (1973) Formation of Magnesian Skarns. Nauka, Moscow, pp 1-173 (in Russian)

SHANNON RD (1976) Revised effective ionic radii and systematic studies of interatomic distances in halides and chalcogenides. Acta Cryst A32: 751-767
Ulrich S, Schulmann K, Casey M (2002) Microstructural evolution and rheological behaviour of marbles deformed at different crustal levels. J Struct Geol 24: 979-995

ŽÁČEK V, FrÝda J, Petrov A, HyrŠL J (2000) Tourmalines of the povondraite-(oxy)dravite series from the cap rock of meta-evaporite in Alto Chapare, Cochabamba, Bolivia. J Czech Geol Soc 45: 3-12 